\title{
Chlamydia pneumoniae IgA Antibody Measurement
}

National Cancer Institute

\section{Source}

National Cancer Institute. Chlamydia pneumoniae IgA Antibody Measurement. NCI

Thesaurus. Code C92432.

The determination of the amount of Chlamydia pneumoniae IgA antibody present in a sample. 